\title{
Down the Rabbit Hole: How Structural Holes in Entrepreneurs' Social Networks Impact Early Venture Growth
}

\author{
Mackenzie Adams, Maged Makramalla, and Walter Miron
}

\author{
"A wise man will make more opportunities than he finds. ") \\ Francis Bacon (1561-1626) \\ Philosopher, statesman, scientist, and jurist
}

\begin{abstract}
Social networks play a significant role in the success of new entrepreneurial ventures. They provide an accumulation of tangible and intangible resources that are linked to entrepreneurial outcomes such as growth and innovation. The structure of social networks, specifically, has been linked to these outcomes; structural holes in social networks have shown an association with entrepreneurial success. Entrepreneurs who have many structural holes in their networks are thought to benefit from a rich source of divergent information.

This article examines the complex nature of the relationships among social networks, formal institutions, and the outcomes of new ventures. It also explores the effects of a social network's structural holes on growth in the early years of a venture's development. We propose that structural holes of a social network, through a mediating role of institutional polycentrism, play an important role in the growth and profitability of a new venture as well as potential threats of exploitation. We then provide recommendations based on the reviewed literature for entrepreneurs and managers of formal institutions.
\end{abstract}

\section{Introduction}

Entrepreneurs build and use social networks to harvest resources necessary for their new ventures' growth, including knowledge, customers, supplies, and capital (Stuart \& Sorenson, 2007). According to Todeva (2011), entrepreneurial networks are composed of a wide range of individuals, organizations, and institutions, including family and friends, customers, professional bodies, government institutions, business partners, vendors, and other entrepreneurs. Each network has a unique structure, diverse qualities, and fulfills a different role for the entrepreneurial venture (Martinez \& Aldrich, 2011; Todeva, 2011). For instance, a professional body is likely to be a strong source of knowledge acquisition and development for a venture. Customers, on the other hand, are likely to expand a venture's consumer base through word-of-mouth communication, in addition to providing feedback on products and services.
In a new venture, an entrepreneur's social networks are critical to outcomes of knowledge and resource gathering. This is especially true for a small venture whereby its products or services are otherwise in development or not known, and thus it may not have developed its own networks (Jones \& Jayawarna, 2010; Rost, 2011). The entrepreneur's networks, thus, act largely as the main networks for the venture itself. The strength of ties to network components, as well as the network's structure, determine the type of support that an entrepreneur gathers, and consequently the impact on outcomes such as growth. For example, multiple strong ties and connections to unrelated components within a network may help an entrepreneur secure new business opportunities and resources despite the double barriers of "newness" and "smallness". When an entrepreneur acts as a bridge between two unrelated individuals or groups within a social network, they are said to occupy a structural hole (Burt, 2000). Structural 


\title{
How Structural Holes in Social Networks Impact Early Venture Growth
}

\author{
Mackenzie Adams, Maged Makramalla, and Walter Miron
}

holes often represent a unique state where the unrelatedness of the two groups in the social network is likely to give an entrepreneur access to heterogeneous ideas and non-overlapping resources. Structural holes have emerged as a source of unique resources for entrepreneurs, and have been related to venture performance, especially in the early stages of development (Aarstad, 2012; Batjargal et al., 2013; Rost, 2011; Sullivan \& Ford, 2014; Cowan \& Jonard, 2007).

This article is structured as follows. First, we provide an overview of social networks and structural holes and discuss their advantages, inherent risks, and effects on entrepreneurial variables. Then, we discuss how institutional contexts impact the development of social networks and the growth of new ventures. We conclude by presenting three lessons for entrepreneurs to help maximize the benefits of social networks and structural holes in the context of weak formal institutions: i) learn from existing success stories on collaborative networks, ii) analyze existing social networks for potential impact on venture outcomes, and iii) assess these networks continuously in response to the shifting needs of the venture.

This article is most relevant to entrepreneurs in the early stages of a venture who must consider the impact of both formal institutions and informal factors (e.g., social networks) on early success; the outcomes include product development and growth, and they provide insights into critical success factors that incorporate institutional contexts. The article is also relevant to those who help educate and support entrepreneurs and can connect them with necessary resources.

\section{Social Networks: Structure and Impact}

Some ties to the social networks of an entrepreneur, such as those to family, friends, or mentors, can be especially strong and reliable (Stam et al., 2014). For new ventures, an entrepreneur leans towards these networks for support because they are likely to have fewer opportunity costs. For example, an entrepreneur who secures a loan from his parents may be able to negotiate a low or zero interest rate and a long repayment period. Unlike a loan from a bank with potentially high interest rates and punitive (for a new company) repayment terms, the opportunity costs of tapping into such a social network are lower.

Social networks to which an entrepreneur has strong ties can, however, lack diversity in terms of resources needed, especially in the early years of a venture. In those cases, entrepreneurs may need to resort to social networks to which they are tied weakly. Granovetter (1983) proposed that weak ties in social networks were significant components of a social structure whereby new or unique information could flow. For example, technology entrepreneurs are likely to require specialized knowledge such as codes and design features that are not available in networks to which they have strong ties. This knowledge may be found in networks, such as professional organizations, to which entrepreneurs have weak ties; for instance, these ties could have high opportunity costs for the venture such as the requirement to purchase knowledge or secure membership. In other words, an entrepreneur may have to "pay to play" when a tie to a social network is weak. For entrepreneurs of new ventures, the challenge is to determine configurations of weak and strong network ties that would provide the greatest benefits against the lowest costs (Jones \& Jayawarna, 2010; Stam et al., 2014).

\section{Social Networks and Structural Holes}

It is not only the strength of ties to social networks, however, that impact an entrepreneur's outcomes. How components of their networks relate and their proximity are also important. Imagine that a new learning software entrepreneur is connected to two online communities that focus on financial support for new ventures. The two communities, $\mathrm{A}$ and $\mathrm{B}$, have a large overlap in members and much of the same information flows through them. Community A members are connected to community B members, and the entrepreneur engages in activities that often include both.

Now imagine that the entrepreneur is also connected to two other online communities, C and D. Online community $\mathrm{C}$ focuses on the latest in pedagogy while community $\mathrm{D}$ focuses on programming and design. Unlike the first pair, the members of this second pair not connected. Each has a circle of contacts, events, and specialization, and each provides the entrepreneur with unique knowledge and information. Burt (1992, 2000, 2002) proposed that an individual who acts as a bridge between two unrelated contacts (C and D) in a social network occupies a structural hole. The learning software entrepreneur is said to occupy a structural hole in their social network, as shown in Figure 1.

Burt used the term to reflect the separation of groups, where each group's members on a side of a hole exchange ideas based on their unique skills and know- 


\section{How Structural Holes in Social Networks Impact Early Venture Growth}

\section{Mackenzie Adams, Maged Makramalla, and Walter Miron}

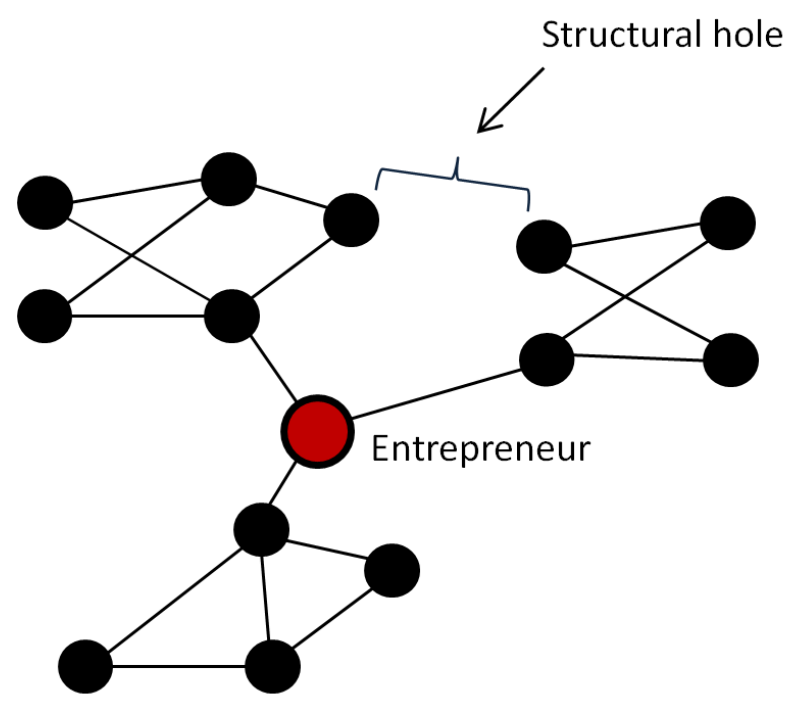

Figure 1. Structural holes in a social network

ledge. The implication is that lack of contact between groups is likely to reduce redundancy in knowledge and overlap in resources as could be seen in the example of online communities A and B. These groups could be business units within the same company, occupying the same building, or across branches, or different groups in other companies and institutions (Burt, 2000).

\section{Advantages of structural holes}

The advantages of structural holes in a social network have been examined by researchers across different industries. Ahuja (2000) explored the relationship between a firm's position in a collaborative network and its innovation output and posited that such networks are key to a firm collecting external knowledge. Ahuja found that structural holes had both a positive and a negative impact on a firm's innovation. The presence of more structural holes in their social networks provided ventures with a diverse source of knowledge and information (Aarstad, 2012). In general, knowledge and resource-sharing benefits of collaborative networks rely on trust and shared norms of behaviour (Bizzi, 2013). These trust and behaviour norms are more likely to be present in strongly tied connections within a network, especially in the knowledge fields. McFadyen, Semadeni, and Cannella (2009) found that scientists who had strong ties within their networks (demonstrated by repeated collaborations with the same authors) and sparse networks (indicating the presence of numerous structural holes) published more often in high-impact journals.

\section{Risks of structural holes}

Inherent risks associated with structural holes differ by the stage of a venture's development. Rowley and colleagues (2000) argued that, when an industry is in its early stages of development, its actors explore different technologies and adopt those technologies rapidly. Thus, access to innovation is important, which necessitates connections to both geographically and technologically distant networks. The benefits of structural holes whereby there is less likelihood of redundant information available to ventures in young industries is weighed against the risk of exploitation (Aarstad, 2012; Ahuja, 2000; Goyal \& Vega-Redondo, 2007).

Other researchers have also noted that structural holes, while beneficial in access to divergent information in many instances, can also pose negative consequences (Bizzi, 2013; Obstfeld, 2005). Obstfeld (2005) argued that the concept of structural holes in a social network is largely based on adversarial relationships whereby the focus is on how much benefit an individual or a firm can extract from members of a network, and that the size of this extraction is maximized based on members not knowing each other. Burt (2000) supported this view by stating that individuals chase after the network benefits of resource sharing through a mechanism whereby "ambiguous or distorted information is strategically moved between contacts by the tertius".

\section{Entrepreneurial factors significant to structural holes}

Despite these potential risks, in addition to innovation, structural holes are associated with positive outcomes for ventures, especially those in early stages of development. Aarstad (2012) proposed that an extensive social network and the presence of structural holes in the network affected entrepreneurial performance positively. The implication is that the numerous ties found in an extensive and rich network provide an accumulation of tangible and intangible resources that are linked directly to entrepreneurial outcomes such as growth and profitability (Baum et al., 2000; Cowan \& Jonard, 2007; Zhao, Frese \& Giardini, 2010; Zaheer \& Bell, 2005).

Inconsistent associations between these outcomes and structural holes, however, provide an impetus to explore potential factors that could impact entrepreneurial ventures (Martinez \& Aldrich, 2011). Ostrom, Schroeder, and Wynne (1993) advanced the position of institutional theorists by proposing that these outcomes are reliant on local institutional contexts. These contexts include the impact of multiple institutions 


\title{
How Structural Holes in Social Networks Impact Early Venture Growth
}

\author{
Mackenzie Adams, Maged Makramalla, and Walter Miron
}

with poly (multi-) centers of decision-making (Ostrom, 2005). Batjargal and colleagues (2013) defined institutional polycentricity as "spontaneous interactions of multiple institutional rules and norms, and mutual adjustments among institutional actors". Against these interactions, entrepreneurs "pursue their goals in polycentric institutional settings where they comply with multiple governance rules at different levels and scales embedded in local knowledge and particular settings".

Thus, the question is whether institutional structures (i.e., polycentricity) would expand on our understanding of the relationship between a network's structural holes and a venture's success. One way to explore this question is to compare how structural holes affect entrepreneurial success in different countries, thereby shedding light on the influence of institutional contexts.

\section{Institutional Order and Social Networks}

The building and cultivation of social networks has been found to be influenced by institutional contexts that determine to a large extent how ventures are regulated and supported and which, in turn, affect the nature of entrepreneurs' social networks (Batjargal, 2010; Baumol, 1990). Literature in this area suggests that institutional polycentrism - whereby a formal institution's rules and norms are created in multiple centres of decision-making - may act as a mediator between structural holes in a social network and a new venture's outcomes such as profitability, growth, and product development (Batjargal et al., 2013; Boettke \& Coyne, 2009). Specifically, research in this area explores how these institutions affect the development of an entrepreneur's social networks and the subsequent impacts a new venture's outcomes. According to Batjargal and colleagues (2013), "the notion of polycentricity refers to a spontaneous order in which multiple and independent decision-making centers and actors make mutual adjustments for ordering their relations within a general framework of rules and norms". A young, entrepreneurial venture is much more sensitive to institutional polycentrism than an older, more established one. A new venture's growth in the early years of development is especially at risk.

\section{Weak and inefficient institutions}

Weak and inefficient political institutions can affect entrepreneurial networking and outcomes. Weak institutions are defined as those that impose unreasonable restrictions on entrepreneurs' social activities. These restrictions are believed to impede entrepreneurs' pur- suit and identification of opportunities, which in turn negatively affect their innovation. Tonoyan and colleagues (2010) found that these types of institutions impose rigid, bureaucratic controls that often lead to bribery and other forms of corruption. For new ventures that cannot manoeuvre or do not have the resources to bypass the bureaucracy, weak institutions significantly hinder entrepreneurial activities.

Similarly, inefficient institutions place severe burdens on new ventures. Inefficient institutions, which are often regulatory bodies, are those with insecure contractual agreements and property rights. When entrepreneurs start or want to grow a venture in a local environment rampant with these institutions, they face uncertain outcomes of their strategic actions. For example, entrepreneurs may be reluctant to purchase land or launch a new product given how their physical or intellectual property may not be fully under the protection of the law (Tonoyan et al., 2010).

\section{New ventures and structural holes in polycentric institutions}

With weak and inefficient institutions, an entrepreneur, especially in the early years of a venture's development, will spend time and resources dealing with these institutions, which reduces the likelihood of entrepreneurial success and increases opportunity costs (Batjargal et al., 2013). A young venture is especially vulnerable to weak economic institutions as much needed capital becomes difficult to access and obtain.

In a study with software ventures that were six years old or younger, both advantages and risks with structural holes were found (Batjargal, 2010). Polycentric institutions affected the relationship between structural holes in the entrepreneurs' social networks and two entrepreneurial outcomes: product portfolio and revenue growth in the early stages of development. Batjargal (2010) found that the effect of structural holes on venture success is dependent on two factors: country institutional context and venture development stage. In general, and especially for ventures in their early years of development, structural holes have a positive effect on product portfolio. According to Batjargal (2010), "structural holes in entrepreneur's personal networks facilitate product development because they provide access to nonredundant information, diverse resources, and third-party referrals. The entrepreneurs whose networks are rich in structural holes combine and re-combine various program codes, modules, functions, design features, and languages to produce software applications for numerous market segments". 


\title{
How Structural Holes in Social Networks Impact Early Venture Growth
}

\author{
Mackenzie Adams, Maged Makramalla, and Walter Miron
}

The combination of weak and inefficient institutions is associated with an increasing number of structural holes in an entrepreneur's social networks. Batjargal and colleagues (2013) found that this combination leads to "negative synergy because of destructive mutual reinforcement and increased institutional contradictions and reversals that disrupt venture growth processes and trajectories". Not surprisingly, these researchers found that an institutional order rife with weakness and inefficiency negatively impacted the revenue growth of new ventures. However, they also found that entrepreneurial networks with rich structural holes reduced this impact by having a positive effect on revenue growth. As seen in Figure 2, weak and inefficient institutions provide an impetus for an entrepreneur to build and use social networks that may provide resources for a new venture.

The mechanism that facilities this positive effect is thought to be due to nonredundant private information that these structural holes provide. In other words, entrepreneurs are able to gain information on new sales opportunities, new products for existing customers, new distribution channels, and new segments for existing products. This divergent information leads to greater sales, which increase revenue growth. The revenue growth impact for new ventures is stronger among en-

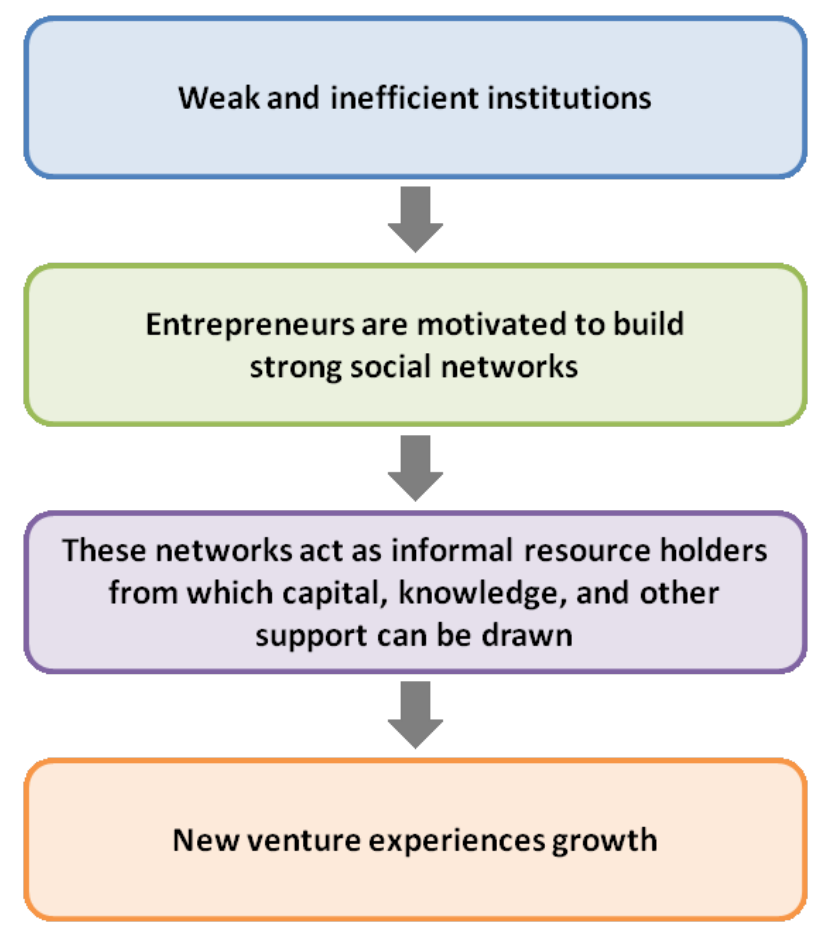

Figure 2. Institutional order and social networks in the outcomes of new ventures trepreneurs who are dealing with weaker and more inefficient institutions. Thus, the worse the institutional context, the greater the impact of structural holes on new ventures' growth.

Structural holes may provide dividends in divergent knowledge acquisition but due to the issues of poor communication and a difficulty in mobilizing revenuegenerating resources, they may not lead to increased revenues in the early years of the venture. Table 1 summarizes how, within institutional contexts, an entrepreneurial venture fares with structural holes given its age. The most vulnerable ventures are young startups (i.e., those less than 5 years old) and those that are largely based on technology or innovation. These companies are often too small, too new, or too cashstrapped to have their intellectual property rights protected by patents and trademarks. Given that their success relies on staying on top of knowledge in their fields, structural holes are a necessity from which they access this knowledge. These companies must engage and connect with others, thereby exposing their products, codes, and functions to more mature companies. Because they are new ventures, the trust and mutual exchange of information is in its infancy and these established companies may very well exploit the new ventures' developments and ideas.

Product-based companies are the least vulnerable and, even though they rely on innovation to remain competitive, they likely have protected themselves with patents and trademarks. For these companies, structural holes are not primarily there to fill gaps in knowledge. Established companies usually build their knowledge centres in-house or commission them to smaller companies. For them, structural holes may provide access to new markets and customers, or help them in market research. Ventures that are knowledge-based, even when not new, may be vulnerable to exploitation if they rely on structural holes in their social networks to fill gaps in their knowledge.

Batjargal's own research $(2003,2007,2010)$ and research with colleagues (2013) is a departure from earlier work on social networks and ventures' growth (e.g., Boettke \& Coyne, 2009; Burt, 2000; Elfring \& Hulsink, 2003; Stuart \& Sorenson, 2007; Tonoyan et al., 2010) in that it elucidates the role of formal institutions to great depths using the concept of polycentrism. Previous work had either studied structural holes in social networks and their impact on venture outcomes, or had studied institutional characteristics in relation to the success of entrepreneurial ventures. 


\title{
How Structural Holes in Social Networks Impact Early Venture Growth
}

\author{
Mackenzie Adams, Maged Makramalla, and Walter Miron
}

Table 1. The influence of venture age and focus on vulnerability to exploitation

\begin{tabular}{|c|c|c|c|c|}
\hline Venture Age & Focus & Intellectual Property & $\begin{array}{l}\text { Dependency on } \\
\text { Structural Holes }\end{array}$ & Vulnerability to Exploitation \\
\hline Older, established & Products & $\begin{array}{l}\text { Likely to have patents } \\
\text { and other protections }\end{array}$ & Low & Very low \\
\hline Older, established & $\begin{array}{l}\text { Products (but reliant on } \\
\text { continuous innovation) }\end{array}$ & $\begin{array}{l}\text { Likely to have patents } \\
\text { and other protections }\end{array}$ & Low & Low \\
\hline Medium-aged & Technology or ideas & $\begin{array}{l}\text { May have patents } \\
\text { and other protections }\end{array}$ & High & Medium \\
\hline Young startups & Technology or ideas & $\begin{array}{l}\text { Unlikely to have } \\
\text { patents and other } \\
\text { protections }\end{array}$ & High & High \\
\hline
\end{tabular}

\section{Recommendations to Entrepreneurs and Managers}

For entrepreneurs to maximize on their social capital benefits, connections to networks must fill in for resources that are otherwise in short supply. New venture entrepreneurs are especially often short on finances, markets, and knowledge, among others, and could learn lessons from using structural holes in their social networks to extract what they need for growth and innovation. The first lesson is to learn what larger, established companies do in fostering collaboration across social groupings to enhance learning (Di Vincenzo et al., 2012), problem solving (Heng \& Loosemore, 2013), and technical innovation. 3M's collaborative approach among scientists of different departments and specializations is credited with its innovation and the exchange of new ideas (Scanlon, 2009). The company built an internal web-based social network called the "Technical Forum" to help its scientists bridge structural holes and harness the creative problem-solving potential of groups previously siloed in their departments or units. Similarly, a group of hospitals used structural holes among its organizations to facilitate the integration of information (Heng \& Loosemore, 2013). How can a new venture, cash-strapped and a newcomer in its industry, emulate $3 \mathrm{M}$ and similar large companies? If large enough as a venture, it can create in-house collaborative platforms whereby people from diverse specializations such as programming or strategy can communicate easily in solving problems (Scanlon, 2009). Regardless of its size, the venture should use existing support networks, especially those online, to ac- cess information. If not available or in existence, then it should build them and encourage individuals, other entrepreneurs, and established organizations to participate.

The second transferrable lesson for new ventures is to recognize the significance of the nature of social networks before bridging structural holes. It is not enough for an entrepreneur to be the only connection between two isolated groups; the groups themselves have to offer access to business opportunities and knowledge needed for innovation and growth. For an entrepreneur, understanding their social networks means a thorough analysis that takes the venture's and its networks' variables into account. In other words, entrepreneurs cannot be in the dark about who can offer them what, especially in the early years of the venture. Fornoni, Arribas, and Vila (2012) studied Argentinian startup entrepreneurs and the impact of their social networks on their performance in accessing markets and information. They found that three dimensions of their social networks had the greatest impact on their performance: "the relational dimension facilitates access to information; the resources dimension makes access to finance easier; the structural dimension helps the entrepreneur to access markets" (Fornoni et al., 2012). Entrepreneurs, especially those of new ventures, will recognize the importance of analyzing their social networks for potential impact on their growth and innovation.

The third lesson for entrepreneurs is to realize that creating and analyzing social networks, and bridging structural holes in them, are not enough. As with every 


\title{
How Structural Holes in Social Networks Impact Early Venture Growth
}

\author{
Mackenzie Adams, Maged Makramalla, and Walter Miron
}

aspect of an early venture's development, social networks change. Some evolve and some disappear. The challenge for entrepreneurs is to assess these networks continuously in response to the shifting needs of the venture (Sullivan \& Ford, 2014). This challenge is especially relevant to new ventures arising or growing in environments with weak and inefficient formal institutions. The survival of the venture in these circumstances relies to a great extent on robust, dynamic social networks that are responsive to ongoing challenges. Therefore, "the character of entrepreneurs' networks should change in both composition and structure to ensure that they include the appropriate mix of partners to gain access to needed resources" (Sullivan \& Ford, 2014).

Based on our review of structural holes in social networks, the role of formal institutions, and new ventures' outcomes, we can offer these further recommendations for entrepreneurs:

1. Identify risks inherent in ideas-based business ecosystems. New entrepreneurs in technology- or innovation-based startups should protect their intellectual property rights as best as possible with patents and trademarks.

2. Conduct a systematic review of financial, knowledge, and networking resources. In the early years of development, new ventures will rely on both institutional support and informal social networks. For knowledge gaps, whereby the greatest risk of exploitation through structural holes occur, entrepreneurs should exhaust institutional sources of this knowledge.

3. Seek institutional support first. Entrepreneurs should explore innovative entrepreneurship and incubation that provide protections for entrepreneurs' ideas and are not likely to share in the mores of traditional polycentric institutions such as government and banks. This recommendation is especially relevant if the institutions are only modestly supportive of entrepreneurship.

4. Protect your "secret sauce". To reduce their risk of exploitation, when new startups and young ventures approach social networks to fill gaps in knowledge, they should be wary of structural holes for resources and protect secrets that will be critical to their success.
And, we offer the following recommendations for managers in formal Institutions:

1. Be knowledgeable of new venture risks and vulnerabilities. Managers in formal institutions should be aware of the vulnerabilities faced by new startups and young ventures regarding intellectual property and knowledge gaps.

2. Provide innovation hubs for idea development. Managers should create these hubs with training and support in intellectual property protection. New startups and entrepreneurs will find an alternative to social networks to gain necessary knowledge. Instead, they will seek these networks for other purposes such as expansion of a customer base.

\section{Conclusion}

Social networks are an essential factor in the success of new ventures (Elfring \& Hulsink, 2003; Martinez \& Aldrich, 2011). New entrepreneurs cannot eliminate all risks that are associated with expanding their social networks, especially those related to structural holes. Similarly, managers in formal institutions cannot protect entrepreneurs and their ventures from inherent risks associated with bringing ideas to the outside world. However, this article has provided a number of recommendations they can use to support ventures in those early critical years.

We have examined how the theory of institutional polycentrism and social network theory explain the role of networks' structural holes in the early success of a new venture. We have also examined how different institutional contexts have a mediating role in this success. The research indicates that ventures, especially in their early stages of development, would benefit potentially from structural holes in outcomes such as product development and revenue growth. New entrepreneurs should, however, reduce their risks of exploitation by protecting their intellectual property rights. 


\section{How Structural Holes in Social Networks Impact Early Venture Growth}

\section{Mackenzie Adams, Maged Makramalla, and Walter Miron}

\section{About the Authors}

Mackenzie Adams is a serial entrepreneur, a Senior Technical Communicator in the Oil and Gas industry, and a graduate student in the Technology Innovation Management (TIM) program at Carleton University in Ottawa, Canada. She is also a Principal at THINQ I/O, a consulting company. Over the past 15 years, Mackenzie has worked in a variety of fields ranging from social work to accounting and has used those experiences to develop strong strategic and analytical skills. She is interested in the fields of artificial intelligence and quantum computing, and how they relate to cybersecurity.

Maged Makramalla is a current graduate student in the Technology Innovation Management (TIM) program at Carleton University in Ottawa, Canada. He holds a Bachelor of Science degree in Mechatronics Engineering from the German University in Cairo, Egypt. For three years, he has been working as Manager of the Sales and Marketing Department of TREND, a trading and engineering company based in Cairo. His primary research interest lies in the improvement of educational techniques by introducing experiential learning into the regular curriculum while promoting gamification of educational methods.

Walter Miron is a Director of Technology Strategy at TELUS Communications, where he is responsible for the evolution of their TCP/IP and optical networks. He has over 20 years of experience in enterprise and service provider networking conducting technology selection and service development projects. Walter is a member of the research program committee of the SAVI project, the Heavy Reading Global Ethernet Executive Council, and the ATOPs $\mathrm{SDN} / \mathrm{nFV}$ Working Group. He is also Chair of the Venus Cybersecurity Corporation and a board member of the Centre of Excellence for Next Generation Networking (CENGN) in Ottawa, Canada. Walter is currently a graduate student in the Technology Innovation Management (TIM) program at Carleton University in Ottawa, Canada.

\section{References}

Aarstad, J. 2012. Do Structural Holes and Network Connectivity Really Affect Entrepreneurial Performance? Journal of Entrepreneurship, 21(2): 253-268.

http://dx.doi.org/10.1177/0971355712449788

Ahuja, G. 2000. Collaboration Networks, Structural Holes, and Innovation: A Longitudinal Study. Administrative Science Quarterly, 45(3): 425-455.

http://dx.doi.org/10.2307/2667105

Batjargal, B. 2003. Social Capital and Entrepreneurial Performance in Russia: A Longitudinal Study. Organization Studies, 24(4): 535-556. http://dx.doi.org/10.1177/0170840603024004002

Batjargal, B. 2007. Comparative Social Capital: Networks of Entrepreneurs and Venture Capitalists in China and Russia. Management and Organization Review, 3(3): 397-419. http://dx.doi.org/10.1111/j.1740-8784.2007.00080.x

Batjargal, B. 2010. The Effects of Network's Structural Holes: Polycentric Institutions, Product Portfolio, and New Venture Growth in China and Russia. Strategic Entrepreneurship Journal, 4(2): 146-163.

http://dx.doi.org/10.1002/sej.88

Batjargal, B., Hitt, M. A., Tsui, A. S., Arregle, J-L., Webb, J. W., \& Miller, T. L. 2013. Institutional Polycentrism, Entrepreneurs' Social Networks, and New Venture Growth. Academy of Management Journal, 56(4): 1024-1049.

http://dx.doi.org/10.5465/amj.2010.0095

Baum, J. A., Calabrese, T., \& Silverman, B. S. 2000. Don't Go It Alone: Alliance Network Composition and Startups' Performance in Canadian Biotechnology. Strategic Management Journal, 21(3): 267294.

doi:10.1002/(SICI) 1097-0266(200003)21:3<267::AIDSMJ89>3.0.CO;2-8

Baumol, W. J. 1990. Entrepreneurship: Productive, Unproductive, and Destructive. Journal of Political Economy, 98(5): 893-921. http://www.jstor.org/stable/2937617

Bizzi, L. 2013. The Dark Side of Structural Holes: A Multilevel Investigation. Journal of Management, 39(6): 1554-1578. http://dx.doi.org/10.1177/0149206312471385

Boettke, P., \& Coyne, C. 2009. Context Matters: Institutions and Entrepreneurship. Foundations and Trends in Entrepreneurship, 5(3): 135-209.

http://dx.doi.org/10.1561/0300000018

Burt, R. S. 1992. Structural Holes: The Social Structure of Competition. In N. Nohria \& R. G. Eccles, Networks and Organizations: Structure, Form, and Action, 57-91. Boston: Harvard University Press.

Burt, R. S. 2000. The Network Structure of Social Capital. In B. M. Staw \& R. I. Sutton (Eds.), Research in Organizational Behavior, 22: 345423. New York: Elsevier Science.

Burt, R. S. 2002. The Social Capital of Structural Holes. In M. F. Guillen, R. Collins, P. England, \& M. Meyer (Eds.), The New Economic Sociology, 148-189. New York: Russell Sage Foundation.

Cowan, R., \& Jonard, N. 2007. Structural Holes, Innovation and the Distribution of Ideas. Journal of Economic Interaction and Coordination, 2(2): 93-110.

http://dx.doi.org/10.1007/s11403-007-0024-0 


\section{How Structural Holes in Social Networks Impact Early Venture Growth}

\section{Mackenzie Adams, Maged Makramalla, and Walter Miron}

Di Vincenzo, F., Hemphälä, J., Magnusson, M., \& Mascia, D. 2012. Exploring the Role of Structural Holes in Learning: An Empirical Study of Swedish Pharmacies. Journal of Knowledge Management, 16(4): 576-591.

http://dx.doi.org/10.1108/13673271211246158

Elfring, T., \& Hulsink, W. 2003. Networks in Entrepreneurship: The Case of High Technology Firms. Small Business Economics, 21(4): 409-422.

http://dx.doi.org/10.1023/A:1026180418357

Fornoni, M., Arribas, I., \& Vila, J. E. 2012. An Entrepreneur's Social Capital and Performance: The Role of Access to Information in the Argentinean Case. Journal of Organizational Change Management, 25(5): 682-698.

http://dx.doi.org/10.1108/09534811211254572

Goyal, S., \& Vega-Redondo, F. 2007. Structural Holes in Social Networks. Journal of Economic Theory, 137(1): 460-492.

http://dx.doi.org/10.1016/j.jet.2007.01.006

Granovetter, M. 1983. The Strength of Weak Ties: A Network Theory Revisited. Sociological Theory, 1(1): 201-233. http://dx.doi.org/10.2307/202051

Heng, H. K. S., \& Loosemore, M. 2013. Structural Holes in Hospital Organisations: Facilities Managers as Intrapreneurial Brokers in the Tertiary Health Sector. Engineering, Construction and Architectural Management, 20(5): 474-487. http://dx.doi.org/10.1108/ECAM-05-2011-0045

Jones, O., \& Jayawarna, D. 2010. Resourcing New Businesses: Social Networks, Bootstrapping and Firm Performance. Venture Capital, 12(2): 127-152.

Martinez, M., \& Aldrich, H. 2011. Networking Strategies for Entrepreneurs: Balancing Cohesion and Diversity. International Journal of Entrepreneurial Behaviour \& Research, 17(1): 7-38. http://dx.doi.org/10.1108/13552551111107499

McFadyen, M. A., Semadeni, M., \& Cannella Jr, A. A. 2009. Value of Strong Ties to Disconnected Others: Examining Knowledge Creation in Biomedicine. Organization Science, 20(3): 552-564. http://dx.doi.org/10.1287/orsc.1080.0388

Obstfeld, D. 2005. Social Networks, the Tertius Iungens Orientation, and Involvement in Innovation. Administrative Science Quarterly, 50(1): 100-130.

http://dx.doi.org/10.2189/asqu.2005.50.1.100

Ostrom, E., 2005. Understanding Institutional Diversity. Princeton, NJ: Princeton University Press.

Ostrom, E., Schroeder, L., \& Wynne, S. 1993. Analyzing the Performance of Alternative Institutional Arrangements for Sustaining Rural Infrastructure in Developing Countries. Journal of Public Administration Research and Theory, 3(1): 11-45. http://dx.doi.org/10.2189/asqu.2005.50.1.100
Rost, K. 2011. The Strength of Strong Ties in the Creation of Innovation. Research Policy, 40(4): 588-604.

http://dx.doi.org/10.1016/j.respol.2010.12.001

Rowley, T., Behrens, D., \& Krackhardt, D. 2000. Redundant Governance Structures: An Analysis of Structural and Relational Embeddedness in the Steel and Semiconductor Industries. Strategic Management Journal, 21(3): 369-386. doi:10.1002/(SICI)1097-0266(200003)21:3<369::AIDSMJ93>3.0.CO;2-M

Scanlon, J. 2009. How 3M Encourages Collaboration. Bloomberg Businessweek. September 1, 2014: http://www.businessweek.com/innovate/content/sep2009/id2009 092_680626.htm

Stam, W., Arzlanian, S., \& Elfring, T. 2014. Social Capital of Entrepreneurs and Small Firm Performance: A Meta-Analysis of Contextual and Methodological Moderators. Journal of Business Venturing, 29(1): 152-173. http://dx.doi.org/10.1016/j.jbusvent.2013.01.002

Stuart, T., \& Sorenson, O. 2007. Strategic Networks and Entrepreneurial Ventures. Strategic Entrepreneurship Journal, 1(34): 211-227. http://dx.doi.org/10.1002/sej.18

Sullivan, D. M., \& Ford, C. M. 2014. How Entrepreneurs Use Networks to Address Changing Resource Requirements During Early Venture Development. Entrepreneurship Theory and Practice, 38(3): 551-574.

http://dx.doi.org/10.1111/etap.12009

Todeva, E. 2011. Entrepreneurial Networks. In G. A. Barnett (Ed.), Encyclopedia of Networks: 261-264. London: SAGE Publications.

Tonoyan, V., Strohmeyer, R., Habib, M., \& Perlitz, M. 2010. Corruption and Entrepreneurship: How Formal and Informal Institutions Shape Small Firm Behavior in Transition and Mature Market Economies. Entrepreneurship Theory and Practice, 34(5): 803-831.

http://dx.doi.org/10.1111/j.1540-6520.2010.00394.x

Zaheer, A., \& Bell, G. G. 2005. Benefiting from Network Position: Firm Capabilities, Structural Holes, and Performance. Strategic Management Journal, 26(9): 809-825.

http://dx.doi.org/10.1002/smj.482

Zhao, X. Y., Frese, M., \& Giardini, A. 2010. Business Owners' Network Size and Business Growth in China: The Role of Comprehensive Social Competency. Entrepreneurship and Regional Development, 22(7-8): 675-705.

http://dx.doi.org/10.1080/08985620903171376

Citation: Adams, M., Makramalla, M., \& Miron, W. 2014. Down the Rabbit Hole: How Structural Holes in Entrepreneurs' Social Networks Impact Early Venture Growth. Technology Innovation Management Review, 4(9): 19-27. http://timreview.ca/article/828 